\title{
The Effect of Computer Assisted Instruction (CAI) on Students' Cognitive Achievement in Chemical Bonding. A Case Study of Schools in the Kwahu East District of Ghana
}

\author{
Nomolox Solomon Kofi Adherr ${ }^{1,2^{*}} \quad$ Mark Wesono Ayiwah $^{3} \quad$ Boi-Doku, Anyetei $^{1}$ \\ 1. Department of Chemistry Education, University of Education, Winneba, Winneba Campus \\ 2. Pope John Senior High and Minor Seminary, Effiduase, Koforidua, E/R, Ghana \\ 3. St. Vincent College of Education, Yendi, N/R, Ghana
}

\begin{abstract}
The study was conducted in the Kwahu East District of the Eastern Region of Ghana to investigate the effect of Computer Assisted Instruction (CAI) on the cognitive achievement of students in chemical bonding. The study employed a quasi-experimental research design implemented by a pre-test post-test control group containing intact, non-equivalent groups of students. The sample size of the study was forty-six (46) students - Twenty-Two (22) in the experimental group and twenty-four (24) in the control group. A researcher-developed instrument, Chemical Bonding Achievements Test (CBAT) was used for the collection of data. The instrument contained twenty (20) questions with a reliability coefficient of 0.72 . The experimental and control groups were taught with CAI and Lecture teaching methods, respectively. Quantitative data collected were analysed descriptively and inferentially. The findings of the study revealed that teaching with CAI significantly enhanced the achievement of students in chemical bonding than those taught with the lecture method. The study further revealed that the performance of low achievers was improved when they had lessons with CAI. The study recommends the immediate implementation of CAI in Chemistry lessons since it could increase students' attendance to class, motivation, attitude and their cognitive achievement in the subject.
\end{abstract}

Keywords: Computer Assisted Instruction, Chemical Bonding Achievements Test, Chemical bonds, Cognitive Achievement

DOI: $10.7176 / \mathrm{JEP} / 10-20-02$

Publication date:July $31^{\text {st }} 2019$

\section{Introduction}

Teaching becomes effective when the approach used for lesson delivery brings about a desirable change in the behaviour of the learner. If learning strategies and students' achievement have to improve, then students should be introduced to more effective, efficient and appropriate teaching approaches (Jack, 2013). It is observed that in many Chemistry classes in Ghana, teachers still apply the old conservative teacher - centred approach of teaching (lecture), where the teacher acts as the repertoire of knowledge and the students, the dormant recipients. In an average Chemistry classroom, one finds a teacher at the blackboard jotting down important facts or dictating notes with students furiously copying all that is written or read. This method trains the students to be good at retrieving information and the rote application of algorithms without proper appreciation of what they are taught.

When abstract and conceptual ideas in Chemistry, for instance, are not well taught, students may be forced to think that these concepts are always confined to the four corners of the classroom. Teacher-centred approaches to teaching cause students to lose interest in a subject and hence, its syllabus (Yunus \& Ali, 2013). The type of teaching approach employed by a teacher to teach Chemistry is related to the attitude of students towards the subject (Aladejana, 2011) and can even distort the way students perceive and retrieve information (Festus \& Ekpete, 2012). When students develop a negative attitude, it correlatively causes students to elicit poor academic achievements (Cheung, 2009).

The use of instructional materials in Chemistry classrooms have several advantages, including the ability of students to perceive what is taught with two senses (seeing and hearing). Furo (2015) opined that instructional materials are the medium by which the senses gain information from the environment. Instructions are useful when verbal information is presented visually in the learning process of the real thing rather than the use of words only (Mayer \& Moreno, 2002). The more senses considered during information dissemination; the easier it is to retain knowledge for meaningful learning to occur. Animated visualisations that show both structures and processes help teachers convey critical scientific concepts in Chemistry to students quickly (Falvo, 2008). The use of excellent and appropriate materials in teaching Science makes lessons interesting, encouraging and makes the difficult concepts easily understood in a more effective way (Kara \& Kahraman, 2008).

Teachers of Chemistry are expected to make lessons student - centred and result oriented. This goal can be achieved when students are willing, and teachers are exposed to the use of appropriate methods and resources in teaching (Adesoji \& Olatunbosun, 2008). In furtherance of a better Chemistry teaching and learning, researchers proposed improvements to the curriculum through the use of technology (Abiola \& Dhindsa, 2012). Siddiqui 
and Khatoon (2013) expressed the view that, although good teaching can facilitate the process of developing proficiency in Science, developing a conceptual understanding of Science is difficult and time consuming if not performed with the help of ICT. Research has proven the benefits of ICT on the quality of education (Al-Ansari, 2006).

Computer-Assisted Instruction (CAI) is diverse and a rapidly expanding spectrum of computer technologies in education that seeks to facilitate the teaching and learning process (Nazimuddin, 2014). It uses the computer to visualise complex objects and to facilitate communication between students and teachers during the teaching and learning process. There is a current trend of research all over the world on the use of computer facilities and resources in enhancing students' learning (Adeniyi \& Yusuf, 2016; Anyamene, Nwokolo, Anyachebelu, \& Anemelu, 2012) and for that matter, the potentials of CAI, cannot be underestimated in the quest to help students in their studies in Ghana. CAI and its various modes of use such as computer simulations, animations and games can support new and old approaches to Science instruction.

The use of CAI in the classroom helps students mentally link abstract representations of the scientific phenomenon with the invisible processes underlying them and the student's observations (Linn, Chang, Chiu, Zhang, \& McElhaney, 2010). The use of CAI offers flexibility in terms of time, space and pace (Yusuf \& Afolabi, 2010). CAI offers students who do not learn with an approach with materials using an entirely different and unique approach, thereby helping both brilliant students as well as the slow learners. CAI is useful for developing interest, positive attitude, promoting retention and improving the achievements of students (Furo, 2015).

This study, therefore, sought to illuminate the effect of CAI on the cognitive achievement of students in chemical bonding. The study became necessary since there seems to be a little study in this area in Ghana, particularly in the Eastern Region.

\section{Statement of the Problem}

According to Aladejana (2013), classrooms in the past were a cycle of memorisation, repetition, and copying of notes, but now, the world's education has been shaped by Information Communication Technology. The use of technology has become an integral part of our everyday lives; at home, students encounter the use of mobile phones, television, computers, internet, and games. A conflict arises when such students get to the classroom and are expected to listen, write and regurgitate information (Aladejana, 2011). The 21st Century classroom must be matched with education, which should be flexible, creative, challenging, and complex (Sowunmi \& Aladejana, 2013).

In many public Senior High Schools in Ghana, the teaching methods employed in teaching Chemistry to a large extent, fall short in its capacity at ensuring that students can visualise essential abstract concepts in a meaningful way. The terrain is an education that requires students to learn by rote ("Chew, Pour, Pass, forget") to pass the West African Senior School Certificate Examination (WASSCE) without gaining any in-depth understanding. The effects of such education cause students to become less motivated, exhibit absenteeism, develop negative attitudes and ultimately elicit low cognitive achievements in the subject.

A revolution in education around the world points out that, compared to other teaching methodologies, the current method of teaching chemical bonding is plagued with many disadvantages, which call for immediate fixing. This study was, therefore conducted to investigate the effect of Computer-Assisted Instruction on the cognitive achievement of students in a chemical bonding lesson.

\section{Research Question}

What is the effect of Computer Assisted Instruction on the achievements of students in chemical bonding?

Based on this question the following null hypotheses were tested in the study;

\subsection{Null Hypothesis 1}

There is no significant difference in the mean achievement scores of students in Chemical Bonding Achievements Test 2 for the experimental and the control group.

\subsection{Null Hypothesis 2}

There is no significant difference in the mean achievement scores of low cognitive students in the experimental after exposure to CAI.

\section{Research Method}

A quasi-experimental research design was adopted for the study. It was implemented by a pre-test post-test control group containing intact, non-equivalent groups of students. The subjects of the study were put into two groups; Control Group (CG) and Experimental Group (EG) by a non-random sampling technique, but based on the results of an administered pre-test before the commencement of the intervention. 


\subsection{Sample Size}

The study sampled third-year Chemistry students in two (2) senior high schools in the Kwahu East District of Ghana. Third-year students were chosen for the study because they had been taught chemical bonding in the first or second year, according to the Ghana Education Service (GES) and West African Examination Council (WAEC) syllabi.

The sample size for the study was forty-six (46) students, thirty-three (33) males and thirteen (13) females. The sample size of the EG was twenty-two (22) whiles the CG comprised of twenty - four (24) students.

\subsection{Instrument}

A researcher-developed Chemical Bonding Achievements Test (CBAT) was the main instrument for the collection of quantitative data. The CBAT was developed to measure students' cognitive achievement in chemical bonding for the EG and CG before and after the implementation of the CAI and lecture lessons, respectively. The instrument was designed based on the GES syllabus, WAEC syllabus, and a lessons plan developed for the study. Selected questions for the CBAT were from past West African Senior Secondary Certificate Examination (WASSCE) Chemistry papers from 1993 to 2015 . CBAT1 and CBAT2 containing equivalent forms of the same questions were used to collect pretest and posttest data, respectively.

Each CBAT contained twenty (20) multiple-choice test items with four (4) options each. A reliability coefficient determined for the CBAT using the Kuder - Richardson - 20 method was 0.72 . The test instrument was face-validated by two senior Chemistry teachers and two Chemistry educators of the University of Education, Winneba.

\subsection{Data Collection and Analysis}

After the permission and familiarisation with students, the researcher with the help of the Chemistry teachers in the selected schools conducted a pre-test using $\left(\mathrm{CBAT}_{1}\right)$ for both groups on the days of commencement in the schools. Each test lasted an hour to minimise pressure on the subjects. The cognitive achievement of the students in the $\mathrm{CBAT}_{1}$ helped the researcher assign the schools into CG (Most performed school) and EG (least performed school).

The study lasted four (4) weeks with the administration of the Chemical Bonding Achievements post-test $\left(\mathrm{CBAT}_{2}\right)$ for the groups. The CBAT was scored with one (1) mark for any correct answer and zero (0) for any wrong answer. The means of the scores were computed and compared inferentially using pair sample t-tests and an independent t-test at 0.05 level of significance. All the data analysis was done using IBM $®$ SPSS Version 25.

\section{Results}

5.1 Null Hypothesis 1

There is no significant difference in the mean achievement scores of students in Chemical Bonding Achievements Test 2 for the experimental and the control group.

The hypothesis was meant to ascertain if there was a significant difference in the means of the experimental and control group in $\mathrm{CBAT}_{2}$. An independent T-test for the statistics was calculated at a 0.05 significance level. The essence of this test was to gather evidence on the effect of CAI on the achievement of students in the experimental group. The test statistics are in table 2.

Table 1. Results of Independent sample T-test and Descriptive Statistics for the Post-test of the Experimental and Control Group

\begin{tabular}{|c|c|c|c|c|c|c|c|c|c|}
\hline & \multicolumn{4}{|c|}{ Groups } & & & \multirow{2}{*}{$\begin{array}{c}95 \% \text { CI } \\
\text { For Mean }\end{array}$} & \multirow[b]{3}{*}{$\mathrm{t}$} & \multirow[b]{3}{*}{ df } \\
\hline & \multicolumn{3}{|c|}{ Experimental } & \multicolumn{3}{|c|}{ Control } & & & \\
\hline & $\mathrm{M}$ & SD & $\mathrm{n}$ & $\mathrm{M}$ & SD & $\mathrm{n}$ & Difference & & \\
\hline Post test & 15.00 & 3.055 & 22 & 11.71 & 3.099 & 24 & $1.460,5.123$ & $3.623 *$ & 44 \\
\hline
\end{tabular}

Evidence form Table 1 shows that the means of the post-test for both the control and experimental group showed significant difference with $(\mathrm{M}=11.71, \mathrm{SD}=3.099)$ and $(\mathrm{M}=15.00, \mathrm{SD}=3.055)$ respectively since $\mathrm{t}(44)=3.623, \mathrm{p}<0.05$.The statistics indicate that students in the experimental group outperformed their counterparts in the control group on the $\mathrm{CBAT}_{2}$ even though the control were better achievers on $\mathrm{CBAT}_{1}$.

\subsection{Hypothesis 2}

There is no significant difference in the mean achievement scores of low cognitive students in the experimental after exposure to CAI.

Low achieving students in this study are students who scored below ten (10) marks in the CBAT . This hypothesis was to determine if the means of the pre-test and post-test of these students were significantly different on the $\mathrm{CBAT}_{2}$. 
Table 2. Results of T-test and Descriptive Statistics for the Pretest and Post-test for low achievers of the Experimental Groups

\begin{tabular}{|c|c|c|c|c|c|c|c|c|c|}
\hline & \multicolumn{6}{|c|}{ Groups } & \multirow{3}{*}{$\begin{array}{c}95 \% \text { CI } \\
\text { For Mean } \\
\text { Difference }\end{array}$} & \multirow[b]{3}{*}{$\mathrm{t}$} & \multirow[b]{3}{*}{$\mathrm{df}$} \\
\hline & \multicolumn{3}{|c|}{ Pre-test } & \multicolumn{3}{|c|}{ Post-test } & & & \\
\hline & $\mathrm{M}$ & SD & $\mathrm{n}$ & $\mathrm{M}$ & SD & $\mathrm{n}$ & & & \\
\hline Low Achievers & 8.00 & 1.414 & 8 & 12.38 & 2.264 & 8 & $-6.696,2.056$ & $-4.460 *$ & 7 \\
\hline
\end{tabular}

Table 2 shows an improvement in the cognitive achievement of low achievers in the experimental group. This is evident in the difference of the means of the pre-test $(\mathrm{M}=8.00, \mathrm{SD}=1.414)$ and the post-test $(\mathrm{M}=12.38$, $\mathrm{SD}=2.264)$ was significant for $\mathrm{t}(7)=-4.460, \mathrm{p}<0.05$

\section{Discussion of Findings}

Data in Table 1 shows a significant difference in the cognitive achievement of the two groups in favour of the experimental group. The cognitive achievement of the experimental group, which at the time of assignment was low, increased significantly in comparison to the control group. The finding gives credence to the fact that the use of CAI affects the achievements of students because of its use of visual imagery to present abstract and confusing topics as opposed to the lecture method that only relied on words and letters for instruction. Additionally, the cognitive achievement may of the EG be attributed to the motivation provided by the CAI; this might have caused students to be more attentive in class as compared to the typical instruction in a lecture class. The use of CAI, according to Wang and his researchers increases the interest of the students and also increases enjoyment and motivation (Wang, Wu, Lu, Fan, \& Lo, 2012).

The finding of the study is similar to a study conducted by Hakverdi-Can and Dana (2012) who concluded that CAI caused students to pay attention to lessons, enhanced students' levels of perception and increases the efficiency of lessons and presentation of different information to students. Anyamene et al. (2012) studying the effect of Computer-Assisted Packages on the performance students in Mathematics also reported that students taught with CAI performed better than students taught using conventional teaching methods. Other studies that also reported the impact CAI on the achievement of students include Nwanne and Agommuoh (2017) and Christmann and Badgett (2003). The findings of Saka (2010) is also in line with the findings of this current study since the study also concluded that CAI significantly increased students' academic achievements. Furthermore, the study's findings are no different from that of Karaçöp (2010), which reported a positive impact on the use of animation on students' achievement.

Again, the study found that the cognitive achievement of the low achievers increased significantly after their exposure to lessons in chemical bonding using CAI. The findings show that CAI is a useful technology tool that can help Chemistry students gain much cognitive gain in their achievement. Computer Assisted Instruction (CAI) is useful for developing interest, positive attitude, promoting retention and improving the achievements of students (Furo, 2015)and that could be the reason for the significant increase in achievement. Similar findings by Owusu, Monney, Appiah, and Wilmot (2010) also suggested that CAI is beneficial for increasing the cognitive achievement of low achievers in a class.

\section{Conclusion and Recommendation}

The study findings show that students taught chemical bonding with CAI became more motivated and paid more attention in class than their counterparts taught chemical bonding using the lecture method. The study also revealed that the cognitive achievement of low achieving students in a chemical bonding class increase after they were taught with CAI.

With the findings presented in the study, stakeholders of Chemistry education should provide schools with the necessary infrastructure for the full implementation of CAI in Chemistry classes to increase students understanding of abstract concepts

The use of visualisation tools as teaching aids leads to motivation, retention of facts, creates a positive attitude and an overall improvement in cognitive achievement and for that matter, urgent attention should be accorded computer literacy in Senior High Schools in Ghana.

Organising of seminars, workshops, and conferences, and the provision of relevant computer-assisted instructional packages would help equip teacher who would intend help to lessen the cognitive load on students due to rote learning.

During the use of CAI, teachers should always link computer visuals to the actual classroom curriculum; besides this, they should create a learning environment that allows student creativity and participation.

Since there are many other difficult and abstract concepts in chemistry, the findings of this work should propel other research in topics like hybridization, chemical equilibrium, energy and energy changes in the Ghanian context.

Stakeholders of education (GES, Ghana Association of Science Teachers (GAST) and Curriculum Research 
Development Division (CRDD)) can use the findings of the study as a guide in the implementation of policies on the integration of ICTs in education in Ghana.

\section{References}

Abiola, O. O., \& Dhindsa, H. S. (2012). Improving Classroom Practices Using Our Knowledge of How the Brain Works. International Journal of Environmental and Science Education, 7(1), 71-81.

Adeniyi, A. E., \& Yusuf, H. O. (2016). Effects of computer assisted instruction on independent learning skills of economics students in secondary schools in Kaduna state, Nigeria. European Journal of Alternative Education Studies.

Adesoji, F. A., \& Olatunbosun, S. M. (2008). Student, Teacher and School Environment Factors as Determinants of Achievement in Senior Secondary School Chemistry in Oyo State, Nigeria. The Journal of International Social Research, 1(2).

Aladejana, F. O. (Ed.) 2011. The child in the 21st century, can ICT change the face of learning?

Aladejana, F. O. (Ed.) 2013. Best Educational Practice as a Panacea to Educational Conflicts in Nigeria.

Al-Ansari, H. (2006). Internet use by the faculty members of Kuwait University. The electronic library, 24(6), 791-803.

Anyamene, A., Nwokolo, C., Anyachebelu, F., \& Anemelu, V. C. (2012). Effect of computer-assisted packages on the performance of senior secondary students in mathematics in Awka, Anambra state, Nigeria. American International Journal of Contemporary Research, 2(7), 61-65.

Cheung, D. (2009). Developing a scale to measure students' attitudes toward chemistry lessons. International Journal of Science Education, 31(16), 2185-2203.

Christmann, E. P., \& Badgett, J. L. (2003). A meta-analytic comparison of the effects of computer-assisted instruction on elementary students' academic achievement. Information Technology in Childhood Education Annual, 2003(1), 91-104.

Falvo, D. (2008). Animations and simulations for teaching and learning molecular chemistry. International Journal of Technology in Teaching and Learning, 4(1), 68-77.

Festus, C., \& Ekpete, O. A. (2012). Improving students' performance and attitude towards chemistry through problem-based-solving techniques (pbst). International Journal of Academic Research in Progressive Education and Development, 1(1), 167-174.

Furo, P. T. (2015). Computer assisted instruction (CAI) and students' interest as determinant of SS II chemistry students' achievement in chemical equilibrium in Rivers State. IOSR Journal of Applied Chemistry (IOSR$J A C)$.[Online], $8(8), 50-56$.

Hakverdi-Can, M., \& Dana, T. M. (2012). Exemplary Science Teachers' Use of Technology. Turkish Online Journal of Educational Technology-TOJET, 11(1), 94-112.

Jack, G. U. (2013). Concept mapping and guided inquiry as effective techniques for teaching difficult concepts in chemistry: effect on students' academic achievement. Journal of Education and Practice, 4(5), 9-15.

Kara, I., \& Kahraman, Ö. (2008). The effect of computer assisted instruction on the achievement of students on the instruction of physics topic of 7 th grade science course at a primary school. Journal of applied Sciences, $8(6), 1067-1072$.

Karaçöp, A. (2010). Öğrencilerin elektrokimya ve kimyasal bağlar ünitelerindeki konuları anlamalarına animasyon ve jigsaw tekniklerinin etkileri. Yayınlanmamış Doktora Tezi, Atatürk Üniversitesi Fen Bilimleri Enstitüsü, Erzurum.

Linn, M. C., Chang, H.-Y., Chiu, J., Zhang, H., \& McElhaney, K. (2010). Can desirable difficulties overcome deceptive clarity in scientific visualizations. Successful remembering and successful forgetting: $A$ Festschrift in honor of Robert A. Bjork, 239-262.

Mayer, R. E., \& Moreno, R. (2002). Aids to computer-based multimedia learning. Learning and instruction, 12(1), 107-119.

Nazimuddin, S. K. (2014). Computer assisted instruction (CAI): A new approach in the field of education. International Journal of Scientific Engineering and Research (IJSER), 3(7), 185-188.

Nwanne, S. C., \& Agommuoh, P. C. (2017). Computer Assisted Instruction (CAI) on Students' Interest and Achievement in Physics in Imo State, Nigeria. Journal of Research and Method in Education, 7(3), 53-58.

Owusu, K. A., Monney, K. A., Appiah, J. Y., \& Wilmot, E. M. (2010). Effects of computer-assisted instruction on performance of senior high school biology students in Ghana. Computers \& Education, 55(2), 904-910.

Saka, A. Z. (2010). Investigation of student-centered teaching applications of physics student teachers. Eurasian Journal of Physics and Chemistry Education, 1(1), 51-58.

Siddiqui, U., \& Khatoon, T. (2013). Teaching physical science: should we implement teacher-centered CAI or student-centered CAI at secondary school level in India? European Scientific Journal, ESJ, 9(10).

Sowunmi, O., \& Aladejana, F. (Eds.) 2013. Effect of simulation games and computer assisted instruction on 
performance in primary science.

Wang, H.-W., Wu, W.-H., Lu, S.-J., Fan, P.-L., \& Lo, Y.-T. (2012). A computer-assisted instruction system with a vision-based interactive interface for children. International Journal of Humanities and Arts Computing, 6(1-2), 172-183.

Yunus, F. W., \& Ali, Z. M. (2013). Attitude towards learning chemistry among secondary school students in Malaysia. Journal of Asian Behavioural Attitude, 3(11), 1-12.

Yusuf, M. O., \& Afolabi, A. O. (2010). Effects of Computer Assisted Instruction (CAI) on Secondary School Students' Performance in Biology. Turkish Online Journal of Educational Technology-TOJET, 9(1), 62-69. 